\title{
THE RULE IN SHELLEY'S CASE IN PENNSYLVANIA
}

\author{
REYNolds D. BRown $\dagger$ \\ Origin of the Rule
}

It is not proposed simply to add one to the long line of discussions of the refinements which present themselves in connection with the Rule in Shelley's case. These discussions have entertained and divided legal thinkers at intervals over the last six hundred years, the most notable instance being the controversy that arose in connection with the views of Lord Mansfield in the famous case of Perrin v. Blake. ${ }^{1}$ Feeling then ran so high that it was said by Lord Campbell in the Lives of the Chief Justices that the bar of the entire kingdom was divided into factions for several years known as Shelleyites and Anti-Shelleyites. It is, of course, well known that in this difference of opinion the Shelleyites prevailed in England, Jesson $v$. Wright, ${ }^{2}$ and Roddy v. Fitzgerald $;^{3}$ though in the opinions in the latter case, as well as as in Jordan $v$. Adams, ${ }^{4}$ the wisdom of the Rule was questioned by at least some of the members of the court. The Rule itself, however, has never been departed from in England. On the other hand, in the United States, in possibly half of the states, statutes have been passed which by one method or another abolish the rule, showing, of course, the distinct trend against the Rule in this country in many directions. What is proposed in this article is the less ambitious but (it is believed) the more fundamental inquiry, namely, that of restating the problem in its simplest terms, inquiring into the rationale of the so-called Rule, and then making a few suggestions as to the desirability of the Rule under the different economic and social conditions of twentieth century life.

To start with, the two simplest and most familiar illustrations will be taken. Suppose that a testator by will in the fourteenth century devised Whiteacre to $A$ for life and after his death to his heirs. Suppose further by the same will he devised Blackacre to $B$ for life with remainder to the heirs of his body (as the date is before the statute of wills, it will be assumed that the land was situated in a jurisdiction where the right to devise by will existed by custom). The first, and it is believed the main, inquiry is: precisely what did the testator mean by these apparently simple provisions? It is, of course, obvious that in both cases he meant that $A$ should enjoy the property during his $\left(A^{\prime} s\right)$ life; and in all the discussions which surround the Rule

†A. B., r890, Harvard University; LL. B., I894, University of Pennsylvania; Professor of Law, University of Pennsylvania Law School; contributor to numerous legal periodicals.

${ }^{1} 4$ Burr. 2579 (r770).

2 Bligh I (1820).

${ }^{3} 6$ H. L. Cas. 823 ( 1858 ).

4 C. B. (N. S.) 483 (I86r). 
in Shelley's case no one has ever questioned this. The real controversy arises with respect to the meaning of the remainder to $A$ 's heirs in the devise of Whiteacre and the remainder to the heirs of $B$ 's body in the devise of Blackacre. The real question is, which one of the two following pictures did the testator have in his mind? Did he, on the one hand, contemplate that upon the death of $A$ Whiteacre should pass to the person or persons who happened to be the heir or heirs of $A$, and similarly that at the death of $B$ Blackacre should pass to the person or persons who happened to be the heirs of the body of $B$, in each instance in their own right? Or did he, on the other hand, contemplate that when $A$ died Whiteacre should pass to his heir or heirs, and thereafter upon the death of such heir or heirs of $A$ should continue to descend to the heirs of $A$ indefinitely, and in like manner in the case of Blackacre did he contemplate that on the death of $B$ Blackacre should pass to the heir or heirs of his body, and on his or their death should still pass to the heir or heirs of the body of $B$ and so on ad infinitum? Without attempting to decide at the moment which of these two pictures the testator had in his mind, it is, of course, obvious that if he had the second picture, the only way in which the law could accomplish that portion of the testator's wishes was to give $A$ an estate in fee simple in the first case and $B$ an estate in fee tail in the second case. It is further obvious that if in order to carry out the testator's wishes with respect to this portion of his devises the law decides to give an estate in fee simple to $A$ and an estate in fee tail to $B$, it must necessarily in so doing disregard the original words of the two gifts by which the testator has in terms prescribed that $A$, in the case of Whiteacre, and $B$ in the case of Blackacre, shall take only a life estate.

In order to understand the probable intent of the testator in such a case in the fourteenth century it is necessary to remind ourselves of certain economic and legal conditions which existed in that time but have been much changed in the intervening centuries. One is the well known fact that at that time conveyances inter vivos were very rare; under the Feudal system they were accompanied by such heavy burdens as to make it very unusual for the owner of land in fee simple to want to convey it. Further the right to devise lands by will at that time did not generally exist, and indeed was only made general by the Statute of Wills in the sixteenth century. Again, lands at that time were not liable to the payment of debts of decedents, even specialty debts. It follows from these facts that if lands were acquired by $A$ in fee simple, while theoretically he might convey them to some third person, yet practically in perhaps ninety-nine cases out of a hundred the lands which he owned in fee simple he held until his death, at which time they passed to his heirs under the intestate laws. This entire situation is summarized in the familiar fact that when lands were to be conveyed to $A$ in fee simple, the correct technical language was a conveyance to $A$ and his 
heirs; it is, of course, elementary that $A$ 's heirs acquired no immediate interest in the lands by such conveyance, and yet the fact that these words were the technical words chosen to create a fee simple is conclusive evidence that in those days a conveyance in fee simple was presumed to pass the title on after $A$ 's death to his heirs indefinitely.

The rules of descent in force at that time and for many centuries afterwards should also be borne in mind. It is, of course, well known that under the common law rules of descent if $A$ died owning lands in fee simple and the lands thereupon passed to his heir $B$, that later upon $B$ 's death the lands passed not to $B$ 's nearest heir but to the next heir of $A$, and so on ad infinitum; in other words the lands passed from $A$ as the source of descent indefinitely until such time as the descent might be broken by a conveyance from the then holders to some third party who became a new source of descent until his line of descent might again be broken by another conveyance.

Still another factor to be borne in mind was the common law rules with respect to inheritance; under those rules, of course, the male heirs inherited in preference to the female and the oldest male heir in preference to younger heirs of the same rank.

Bearing in mind these familiar facts, was it more likely that the testator or draftsman of his will in the fourteenth century when lands were devised to $A$ for life, remainder to his heirs, intended simply to benefit the person or persons who might be $A^{\prime} s$ heir or heirs at the moment of $A^{\prime}$ 's death, thus making such heir or heirs a new source of descent of the lands in question, or was it more likely, on the other hand, that he intended that $A$ 's heir or heirs should take not in their own right but by descent from $A$, and that the lands should pass on later upon the death of such heir or heirs to the person or persons who might then be the heir or heirs of $A$ ? According to the Rule in Shelley's case the latter is regarded as the real intention, and it is submitted that there is much to be said in favor of this view. The word "heirs" in a jurisdiction where a single male heir always took to the exclusion of the other male and female relatives in itself seems to imply that the testator had in mind not a single gift to a single individual, but rather a series of successive gifts to those who might occupy the relation of heirs to $A$ for the indefinite future. Similarly in the case of the gift of Blackacre to $B$ for life, remainder to the.heirs of his body, - the familiar estate tail, of course, was created by the technical gift to $B$ and the heirs of his body; no one doubted that in such case the heirs of the body of $B$ were his descendants throughout all generations, as opposed to his children; in the case therefore of a gift after a life estate to $B$ of a remainder to the heirs of his body, the implication that the beneficiaries were intended to be $B$ 's descendants indefinitely and successively was very strong. Still another argument pointing in the same direction was the fact that at that time words of inheritance were necessary to create either a fee simple or a fee tail; it was therefore no slight objection to construing the word heirs in the first case or the expression heirs of the 
body in the second case as limited exclusively to the persons who answered such description upon the death of $A$ and $B$ respectively, that there were no words of inheritance attached to the gifts in the one case to the heirs of $A$ or in the other to the heirs of the body of $B$. Certainly if it was desired that given individuals who occupied such relation to $A$ and $B$ should take either estates in fee simple or estates in fee tail in Whiteacre and Blackacre, the appropriate (and perhaps the necessary) way to bring about such result would have been to devise Whiteacre to $A$ for life with remainder to his heirs and their heirs and assigns, and to devise Blackacre to $B$ for life with remainder to the heirs of his body and their heirs (if it was desired that they should have a fee simple) or some appropriate language if it was desired that they should have a fee tail in their own right.

Again obviously the objection to the successive view that this would require giving $A$ in the first illustration a fee simple and $B$ in the second illustration a fee tail contrary to the expressed intention of the testator that they should have only life estate (which objection if the question were to arise today for the first time would doubtless be a serious one) was largely met by the fact above stated, namely that in the fourteenth century, whether $A$ got a life estate only or a fee simple, it was almost equally certain that the land would pass at his death to his heirs.

Perhaps the real fact is that in this instance, as in so many other instances in the law of property, it is a mistake which has frequently been made to assume that a testator when making his will had a very definite intention which the law must carry out; the real fact probably is that in many cases of ambiguous language in wills, either the ambiguous language is due to a careless draftsman and adopted by an innocent testator who assumes that the draftsman correctly carried out his expressed wishes, or if the testator has drafted his own will, while he, of course, must have had a general purpose in mind, it by no means necessarily follows that his purpose was sufficiently well developed to cover such difficulties as those now being discussed. More concretely, it is possible that in such a case the testator devised Whiteacre to $A$ for life with remainder to $A$ 's heirs and devised Blackacre to $B$ for life with remainder to the heirs of his body without thinking the matter through, so that it is quite possible that if asked at the moment that he made the will whether he intended the heir or heirs of the body to take as individuals in their own right or to take successively through numerous generations from $A$ or $B$, he would reply that he had neither of these alternatives definitely in his mind. The law, however, must assume that he had one or the other in mind, and the Rule in Shelley's case assumes, and the writer believes with a strong probability in favor of the propriety of the Rule, that the testator had a succession of heir or heirs of the body in his mind, or at least that this is the more likely alternative of the two. 
At this point the writer wishes to emphasize the thought that in his judgment the sole justification for the Rule in Slielley's case. is the belief on the part of the court that in attributing this indefinite succession of heirs or heirs of the body to the testator the law is really carrying out the testator's wishes as nearly as it can. Manifestly in the case of the gift to $A$ for life, remainder to his heirs, if the law in the fourteenth century were to give a life estate only to $A$ with a remainder in fee simple to his heir or heirs, what must happen would be that at $A^{\prime}$ s death certain person or persons who constitute $A$ 's heirs would then take a fee in their own right, and that the fee (if fee he had) would pass at the death of such heir or heirs to his heir or heirs as opposed to the testator's heirs. In other words, the only possible way in which the land could pass in the first illustration to $A^{\prime}$ 's heirs indefinitely and in the second illustration to the heirs of $B$ 's body indefinitely would be for the law to give $A$ a fee simple in the first illustration and to give $B$ a fee tail in the second illustration. The writer, therefore, strongly protests against the innumerable statements by courts and text writers to the effect that the Rule in Shelley's case is not a Rule of construction intended to carry out the testator's intention, but a Rule of law or a Rule of property which must be relentlessly enforced in spite of the fact that it does not carry out the testator's intention. It is doubtless true that in every case where the Rule is applied, that portion of the testator's intention which specifies that the ancestor should take only a life estate is contravened when the Rule gives the ancestor either an estate in fee simple or an estate in fee tail, as the case may be; the point is that when the Rule does this, it is not willfully flying in the face of the testator's intention, but on the contrary is disregarding what it believes to be the less important part of his intention in order that what it believes to be the more important part, namely, that the same shall descend from the ancestor in fee simple or fee tail indefinitely, may be carried out. The writer further believes that the use of the expressions "general intent" and "special intent" so common in the discussion of this problem is also undesirable; carefully analyzed, "general intent" seems to mean the intent of a testator that the land shall pass indefinitely to the heirs or the heirs of the body of the ancestor, whereas "special intent" refers to the contradictory intent of the testator that the ancestor shall have only a life estate. It is true, as above pointed out, that the Rule in Shelley's case does emphasize and carry out the supposed wish of the testator for the indefinite succession as opposed to the expressed wish of a life interest in the ancestor, but it is believed that the expressions "general intent" and "special intent" do not convey to the mind the thoughts above referred to, and that the terminology of the law would therefore be improved if these expressions should be abandoned, and if the proper function of the Rule in Shelley's case was stated to be, not a choice between a so-called "general intent" and "special 
intent", but the attitude of trying to carry out a somewhat contradictory will in a way which on the whole should come most closely to carrying out the intention of a testator whose entire wishes (though he did not know it) the law is unable to carry out.

Perhaps this is the proper point at which to express the writer's strong opinion that the sole object of the Rule should be (as above pointed out) to carry out the intent of the testator as far as possible. A number of other considerations are consiantly referred to in the literature on the subject as if they constituted adequate reasons for the existence of the Rule. One is that it was adopted to protect the Feudal Lords from the loss of certain perquisites attending the passing of an estate by descent which they did not receive when the estate went by purchase; but it is conceived that this is not, or at least should not be, treated as a proper consideration at all. If it were clear that the testator wanted the land to go to the heir by purchase and not by descent, as the testator had a clear right to so prescribe, the Rule would have imposed a very unjust restriction on the power of the testator to dispose of his own property which, it is submitted, can only be justified on the assumption that the testator intended a successive inheritance; if the testator did intend such successive inheritance then it of course followed that the heirs took the property by descent subject to these feudal reliefs which were properly payable in such cases. Again, it is frequently suggested (originally by Sir William Blackstone) that one object of the Rule is "to facilitate the alienation of land and to throw it into the track of commerce one generation sooner by vesting the inheritance in the ancestor." Judge Blackstone in Perrin v. Blake seems to express his approval of such policy, but it is submitted that there is an obvious fallacy in this contention. It seems to presuppose that the law does not permit the creation of a life estate followed by a remainder, but, of course, that is not the case; it never has been a part of the policy of the common law to describe or destroy life estates for the purpose of removing clogs upon the alienation of land. Judge Weaver in Doyle v. Andis, ${ }^{5}$ seems to successfully explode the theory that the Rule can be justified because the effect of it, where it is invoked, is to facilitate alienation. Other similar statements may be found but will not be separately discussed. The writer is firmly convinced that all such statements are merely statements of the incidental effects of the Rule where it is applied, but that the question whether the Rule should be applied (with whatever incidental effects) is wholly a question of trying to carry out the testator's intent as nearly as possible, and that the Rule must stand or fall, depending upon whether it does accomplish this laudable purpose, and quite without reference to the incidental effects of the application of the Rule.

${ }^{5}$ 127 Iowa 36,102 N. W. I77 (1905). 
The cases heretofore considered have been the simplest cases, $i . e$, the devise to $A$ for life, remainder to his heirs and the devise to $B$ for life, remainder to the heirs of his body. It is, however, obvious that while the words "heirs" and "heirs of the body" are the expressions which present the question as to the desirability of the Rule in Shelley's case in the plainest form, yet there are innumerable somewhat related expressions which in their more complicated forms bring out further the attitude of the courts with respect to the Rule in Shelley's case. In other words, assuming that a gift to $A$ for life with the remainder to his heirs should give $A$ a fee simple for the reasons heretofore discussed, and that a gift to $B$ for life, remainder to the heirs of his body should give $B$ a fee tail for the same reasons, yet a doubt may exist whether the same reasoning should lead to the same conclusion in other cognate cases, as for example a gift to $A$ for life, remainder to his "heir"; or a gift to $A$ for life, remainder to his heir male; or a gift to $A$ for life, remainder to his heirs in fee simple, etc., etc. It is proposed before taking up the cases in Pennsylvania to briefly consider how such related expressions have been dealt with in England, only premising that the attitude of the courts in considering whether to extend the Rule from its original case to these cognate cases will almost inevitably depend upon the extent to which the courts really believe in the original Rule. Manifestly those courts which firmly believe in the Rule will be inclined to extend it to all similar cases unless it is quite clear that they do not come within the spirit of the Rule, whereas courts which do not agree in the value of the Rule itself, though bound to follow it in the simpler cases, will be apt to seek grounds for discrimination in other cases not within the letter of the Rule.

\section{Further Development of the Rule}

For reasons which, in the light of existing conditions, seem to have been quite adequate, the Rule in Shelley's case seems to have at first met the unanimous approval of the profession. It is well known that the principle of the Rule was applied as early as 1324, although the Rule was not in terms stated in the short opinion in the year books. It seems to have been tacitly applied in several other cases before Shelley's case itself, where it was discussed and formally adopted. In its simplest form, at least when formally adopted, it seems to have encountered no opposition. But almost immediately after its adoption the question arose as to whether it should be applied to somewhat similar, though not precisely equivalent, facts. Suppose, for example, land was devised to $A$ for life, remainder to his heir male; or to his heir for life, remainder to his heirs in fee simple; or to $A$ for life, remainder to his heirs and their heirs and assigns; or to $A$ for life, remainder to his heirs as tenants in common; or to $A$ for life, remainder to his heirs 
then living. These are simply a few of the many possible variations which might arise and which, in fact, did begin to confront the courts almost from the moment of the formal adoption of the Rule in Shelley's case.

It is quite obvious that in solving the problem whether the Rule in Shelley's case should apply in these similar cases there were two possible methods by which the courts might approach the solution of the difficulty. They might either on the one hand say that the sole test whether the Rule should apply was whether the language used by the testator, no matter what the express words used, conveyed the idea that after $A$ 's death either all of his heirs or all of his descendants were to take successively for all time to come; if this were the correct principle it should be held that the Rule in Shelley's case did not apply to any case where for whatever reason the testator shows that either certain heirs or certain descendants should take in their own right and to the exclusion of other heirs or other descendants of $A$. Or, on the other hand, disregarding the principle above suggested, it might be held that the Rule in Shelley's case should be extended to arbitrarily cover certain groups of cases even though the testator did not intend his entire line of heirs or heirs of the body to benefit; it should be carefully noted that this second view is not a logical one based upon any principle, but an arbitrary one based upon the thought that the Rule in "Shelley's case produces such desirable results that the courts will apply it to analogous situations in spite of the fact that the principle on which it was originally adopted admittedly does not apply. It is proposed to examine a few leading cases in England in order to try to determine which of these two points of view has found favor with the English Court.

The first of these cases is Archer's Case. ${ }^{6}$ There there was a devise to $A$ for life, remainder to his "next heir male" and "to the heirs male of the body of such next heir male". . It seems to have been conceded that the word "heir", though in the singular number, was primarily equivalent to "heirs" so that the Rule in Shelley's case would apply so far as the remainder to the "next heir male" was concerned. The difficulty in the mind of the court apparently grew out of the further words "to the heirs male of the body of such next heir male". After careful consideration it was held that these super-added words indicated that the person who might prove to be $A$ 's next heir male was intended to become a new source of descent,. and hence the Rule in Shelley's case did not apply and $A$ took only a life estate with a contingent remainder to his next heir male. It is submitted that this decision was entirely in accord with the principle above stated, and if it had been properly followed out in the later decisions the propriety of the Rule would not have become questioned.

${ }^{\circ} \mathrm{I}$ Co. $66 \mathrm{~b}(1676)$. 
The next case to which attention will be called is Perrin v. Blake. ${ }^{7}$ By his will the testator devised the residue of his estate to a son John for life with remainder to the heirs of his body, so that the Rule in Shelley's case would obviously apply. The doubt was raised by the further provision that "it is my intent and meaning that none of my children should sell or dispose of my estate for a longer term than his life". John, claiming an estate tail, suffered a recovery and the question before the court in a feigned issue was the extent of John's estate under his father's will. It was held by the Court of King's Bench, Lord Mansfield presiding and against the dissent of Yates, J., that John took only an estate for life, but this ruling was reversed by the Court of Exchequer Chamber which held by a vote of six judges to three that John took an estate tail. The case raised very clearly the question whether the expressed intent on the part of the testator that $A$ should have only a life estate was enough to prevent the Rule in Shelley's case from being applied. Lord Mansfield seems to have been the proponent of the view that there was something absurd in the law giving $A$ an estate in fee simple or in fee tail when the testator has quite definitely stated that he should have only a life estate. The case gave rise to much discussion. Mr. Fearne in his work on Remainders ${ }^{8}$ bitterly attacked Lord Mansfield's views, and Junius in one of his famous letters accused Lord Mansfield of attempting to subvert the laws of England. It is submitted, however, that the opinion of the majority of the Exchequer Chamber, and especially Judge Blackstone's opinion reported in full in Hargrave's Law Tracts, ${ }^{9}$ show convincingly that the Rule was properly applied in that case. If in the simpler case where land is devised to $A$ for life, remainder to his heirs, the law in its wisdom deems that it best fulfills the testator's wishes by giving $A$ a fee simple which might ultimately descend to all of his heirs, what real justification would the courts have for distinguishing a case like Perrin v. Blake where the testator has again devised land to $A$ for life, remainder to his heirs, and then added in effect his wish that the Rule should not apply? It is quite manifest that if he knew of the existence of the Rule he did not want it to apply because he said that $A$ should only have a life estate; the only difference in Perrin $v$. Blake was that he there said expressly (what he says impliedly in every case where the Rule does apply) namely that he only wanted $A$ to have a life estate. If the reasoning on -which the Rule is justified is sound at all, it is submitted that it applies equally whether the testator expressly or impliedly desires that it shall not; but it must not be forgotten that it is of the essence of the Rule that though the Rule disregards the express or implied desire that $A$ shall have only a life estate, it does so only because to give $A$ the

${ }^{7}$ I W. B1. 672 (I769).

${ }^{8} 2$ FEARNe, ReMainders (4th Am. ed. 1845) 205.

"i Hargrave, Law Tracts (I787) 487. 
larger estate is the only way in which the testator's intent that the estate shall pass on through $A$ 's heirs, or the heirs of his body, can be carried out.

The next important case is Jesson $v$. Wright. ${ }^{10}$ In that case the testator devised a certain piece of land to a nephew William Wright for life, then "unto the heirs of the body of the said William, son of my said sister Ann Wright, lawfully issuing in such shares and proportions as he the said William shall by deed or will give, direct, limit or appoint and for want of such gift, direction. limitation or appointment, then to the heirs of the body of the said William, son of my said sister Ann Wright, lawfully issuing share and share alike as tenants in common, and if but one child the whole to such only child, and for want of such issue", then over.

The question was whether William had a fee tail which could be enlarged by the recovery suffered to a fee simple, or whether (the Rule not applying) William had only a life estate. The Court of King's Bench held that William had only a life estate. This was reversed by the House of Lords, Lord Eldon, writing one of the opinions, referring with approval to the old statement of the Rule "that where there is a particular and a general intent, the particular is to be sacrificed to the general intent." He admits the force of the argument "that the appointment could not be to all the heirs of the body in succession forever, and therefore that it means a class or class of persons to take by purchase; that the descendants in all time to come could not be tenants in common; that 'heirs of the body' in this part of the will must mean the same class of persons as the 'heirs of the body' among whom he had before given the power to appoint; and inasmuch as you here find a child described as an heir of the body you are, therefore, to conclude that heirs of the body mean nothing but children." In spite of this position, which seems to be an admirable exposition of the contention that the words "heirs of the body" in the instant case should have been construed as words of purchase, he nevertheless holds to the contrary on the ground that "because children are included in the words 'heirs of the body' it does not follow that heirs of the body must mean only children where you can find upon the will a more general intent comprehending more objects." $\mathrm{He}$ therefore concludes that it is clear that the testator intended that all the issue of William should fail before the estate should go over, though regretting his own decision. Lord Redesdale gave a concurring opinion; rejecting the dictum that "the general intent should overrule the particular", he declares "the Rule is that technical words shall have their legal effect unless from subsequent inconsistent words it is very clear that the testator meant otherwise." In passing, this principle is, it seems to the writer, exceedingly helpful, but on the question whether the technical words in the instant case, to wit "heirs of the body", were not clearly intended to mean otherwise than

${ }^{10}$ Supra note 2 . 
descendants, the writer is by no means persuaded that the decision is correct. If the principle which has been proposed as the correct one upon which the Rule in Shelley's case really should be rested is sound, $i$. e., that it exists in order to carry out the testator's intent that the land shall pass indefinitely to the heirs of the body of the first taker, has not a testator who has directed that the land shall pass at the death of William not simply to his heirs of the body but to his heirs of the body "as tenants in common" shown quite clearly that if and when William died leaving children, instead of the land passing to his oldest son to the exclusion of the other sons and daughters, the testator desires that all his children shall share equally? Has not such testator clearly shown that instead of William being a source of descent from whom all of his descendants shall afterwards take in the order prescribed by the English rules of inheritance, what he really wants is that at William's death his descendants shall take in equal shares-which is something very different from what an estate tail in William would give to his descendants? Finally, if there were serious doubt on this score, is it not entirely relieved by the further clause giving William a power of appointment among such heirs of the body-which power certainly can not be exercised among all his descendants and may therefore fairly be construed as limited to William's children? It is earnestly contended that Jesson $v$. Wright, following certain earlier decisions by the lower courts really unjustifiably extends the Rule in Shelley's case beyond its original scope to a case where on any fair construction of the will the testator's wishes are to be destroyed; the Rule of course avowedly disregards the testator's will in every case to which it applies by giving $A$ a fee simple or a fee tail instead of life estate; this much the Rule may properly do out of a desire to carry out in as broad a sense the wishes of the testator, but the Rule seems to lack any justification if it be extended to include a case where the application of it will not only give the first taker a larger estate than the testator intended, but will do so in spite of the fact that the result is to benefit the heirs or descendants of the first taker indefinitely, whereas the testator did not contemplate benefiting them indefinitely but only contemplated giving certain of them a new inheritable estate at $A$ 's death.

The difficulties into which Jesson $v$. Wright led the English Courts is vividly illustrated in Jordan $v$. Adams. ${ }^{11}$ In that case a testator had devised the lands in dispute to trustees for the use of William Jordan for life, after his decease "to permit and suffer the heirs male of the body of the said William Jordan to occupy the same or receive the rents and profits thereof for their several natural lives in succession according to their respective seniorities or in such parts and proportions, manner and form and amongst them as the said William Jordan, their father, should direct, limit

${ }^{11}$ Supra note 4. 
or appoint; and in default of such issue male of the said William Jordan", to a brother, Richard Jordan, and his descendants. The Common Pleas decided that William took only a life estate and this decision was affirmed by an equally divided court, Barons Channell and Martin holding that William took an estate tail whereas Justice Wightman and Chief Justice Cockburn held that William took only a life estate. Baron Channell relied principally on the dictum of Lord Redesdale in Jesson $v$. Wright, and contended that the argument that the words "their father" in the power of appointment showed that the prior words "heirs of the body" were to be read as sons was unsound, because it would lead to the construction that "if William Jordan had died having had an only son who had died in his lifetime but had left a son who survived his grandfather such grandson would take nothing under the will." Baron Martin repeated the same thought and arrived at the same construction. Justice Wightman disagreed, saying "though by the use of the words 'heirs male of the body' the testator may be supposed to have intended to give an estate tail to the plaintiff, as those words standing alone and unexplained by the rest of the clause would be words of limitation and not of purchase, yet the subsequent words that they (the heirs male) are to take the profits of the estate for their natural lives in succession according to their respective seniorities or in such manner as their father shall by deed or will direct, show too clearly in my opinion to admit of doubt that the testator by 'heirs male of the body' meant the 'sons' of the plaintiff who were to take in succession for life or in such parts and proportions between them as their father should direct."

[To be concluded] 